\title{
PENGUJIAN KARAKTERISTIK DAN KANDUNGAN LEMAK KASAR SILASE PAKAN KOMPLIT YANG BERBAHAN DASAR ECENG GONDOK (Eichornia crassipes) DENGAN LAMA FERMENTASI YANG BERBEDA
}

\author{
(Testing of the characteristics and content of the silage of raw fats \\ complete silage based on hyacinth (Eichornia crassipes) \\ with different fermentation times) \\ D. Yuvita ${ }^{1 *}$, J. Mustabi $^{2)}$, A. Asriany ${ }^{2)}$ \\ ${ }^{1)}$ Mahasiswa Program Strata Satu Fakultas Peternakan, Universitas Hasanuddin. \\ ${ }^{2)}$ Fakultas Peternakan, Universitas Hasanuddin. \\ *Email: dinayuvi917@gmail.com
}

\begin{abstract}
Hyacinth (Eichornia crassipes) is a type of aquatic weed that has potential as an alternative feed. This study aims to examine the characteristics and the crude fat content of complete silage based on water hyacinth with different fermentation times. This study uses a completely randomized design (RAL) with 4 treatments and 4 replications. P1 (0 days or controlled fermentation time), P2 (10 days of fermentation), P3 (20 days of fermentation) and P4 (30 days of fermentation). Statistical analysis showed that a different fermentation time had a significant effect $(\mathrm{P}<0.05)$ on the $\mathrm{pH}$ content but did not significantly affect $(\mathrm{P}>0.05)$ on the fat content raw of complete silage. The average $\mathrm{pH}$ content is $\mathrm{P} 0=7 ; \mathrm{P} 1=5.32 ; \mathrm{P} 2=$ $4.18 ; \mathrm{P} 3=4.21$. The average crude fat content is $\mathrm{P} 0=0.93 \% ; \mathrm{P} 1=1.25 \% ; \mathrm{P} 2=$ $1.22 \%$; and $\mathrm{P} 3=0.92 \%$. Based on research, it was concluded that complete feed silage made from water hyacinth (Eichornia crassipes) was included in the right category based on trait tests. The fermentation time of 20 days is the best to make a complete silage based on hyacinth.
\end{abstract}

Keywords: Characteristic test, Crude Fat, Hyacinth, Complete Silage and Fermentation

\begin{abstract}
ABSTRAK
Eceng Gondok (Eichornia crassipes) merupakan salah satu jenis gulma air yang memiliki potensi sebagai bahan pakan alternatif. Penelitian ini bertujuan untuk mengkaji karakteristik dan kandungan lemak kasar silase pakan komplit berbahan dasar eceng gondok dengan lama fermentasi yang berbeda. Penelitian ini menggunakan Rancangan Acak Lengkap (RAL) dengan 4 perlakuan dan 4 ulangan.Perlakuan P1 (lama fermentasi 0 hari atau kontrol), P2 (lama fermentasi 10 hari), P3 (lama fermentasi 20 hari) dan P4 (lama fermentasi 30 hari).Analisis statistik menunjukkan bahwa lama fermentasi yang berbeda berpengaruh nyata $(\mathrm{P}<0,05)$
\end{abstract}


terhadap kandungan $\mathrm{pH}$ tetapi tidak berpengaruh nyata $(\mathrm{P}>0,05)$ terhadap kandungan lemak kasar silase pakan komplit. Rataan kandungan $\mathrm{pH}$ yaitu $\mathrm{P} 0=7 ; \mathrm{P} 1=5,32 ; \mathrm{P} 2$ $=4,18 ; \mathrm{P} 3=4,21$. Rataan kandungan lemak kasar adalah $\mathrm{P} 0=0,93 \% ; \mathrm{P} 1=1,25 \%$; $\mathrm{P} 2=1,22 \%$; dan $\mathrm{P} 3=0,92 \%$. Dari penelitian disimpulkan bahwa silase pakan komplit yang berbahan dasar eceng gondok (Eichornia crassipes) termasuk dalam kategori baik berdasarkan pengujian karakteristik.Lama fermentasi 20 hari adalah yang terbaik dalam pembuatan silase pakan komplit berbahan eceng gondok.

Kata kunci: Pengujian Karakteristik, Lemak Kasar, Eceng Gondok, Silase Pakan Komplit dan Fermentasi

\section{PENDAHULUAN}

Pakan merupakan salah satu faktor yang mempengaruhi pertumbuhan dan produktivitas ternak.Dalam pengembangan produksi ternak ruminansia di Indonesia permasalahan yang dihadapi adalah sulitnya memenuhi ketersediaan pakan.Produktivitas hijauan sangat berfluktuasi, berlimpah pada musim hujan, terjadi kekurangan saat kemarau pada daerah padat ternak.Usaha mencari bahan pakan murah dan penemuan teknologi tepat guna dalam pemanfaatannya masih terus dilakukan, guna membantu pemecahan penyediaan pakan.

Eceng gondok (Eichhornia crassipes) adalah salah satu jenis gulma air yang perkembangannya sangat cepat dan mempunyai daya penyesuaian terhadap lingkungan yang tinggi (Fuskhah, 2000). Eceng gondok memiliki potensi sebagai bahan pakan alternatif. Kandungan nilai gizi eceng gondok sebagai berikut: kandungan protein kasar 9,8-12,0\%, abu 11,9-12,9\%, lemak kasar 1,1-3,3\%, dan serat kasar yang cukup tinggi yaitu 16,8-24,6\%. Terlebih lagi eceng gondok sebagai bahan pakan alternatif sangat mudah untuk didapatkan karena bahan ini banyak tersedia di alam dan masih belum dimanfaatkan dengan baik (Riswandi, 2014).

Kendala dalam pemanfaatan eceng gondok adalah bersifat volumneous dengan serat kasar tinggi dan protein kasar rendah sehingga palatabilitas dan daya cerna juga rendah.Peningkatan nilai manfaat limbah sebagai pakan ternak dapat dilakukan dengan peningkatan nilai nutrisi melalui perlakuan dan pengolahan baik fisik, kimia dan biologi tergantung pada jenis asal dan faktor pembatas (Marlina dan 
Askar, 2001). Salah satu cara memanfaatkan limbah eceng gondok agar memberi nilai tambah adalah pengolahan dalam bentuk silase.

Silase merupakan hasil dari penyimpanan dan fermentasi hijauan segar dalam kondisi anaerob. Silase dengan mutu baik diperoleh dengan menekan berbagai aktivitas enzim yang tidak dikehendaki serta mendorong berkembangnya bakteri asam laktat yang ada pada bahan.

Indikator keberhasilan silase dapat dilihat dari bahan yang digunakan dalam pembuatan silase, sehingga dihasilkan kualitas silase yang baik. Salah satu faktor yang mempengaruhi kualitas silase dapat dilihat dari karakteristik silase, suhu serta pH. Selain itu perlu diketahui kandungan nutrisi pada silase tersebut salah satunya kandungan lemak kasar. Lemak berfungsi sebagai pemasok energi bagi tubuh. Kandungan lemak dalam pakan perlu diperhatikan, jika lemak terlalu tinggi atau rendah dapat mempengaruhi kondisi ternak, status faal, status fisiologi dan produks ternak. Hal inilah yang melatarbelakangi dilakukannya penelitian ini. Tujuan dalam penelitian ini adalah untuk mengetahui karakteristik dan kandungan lemak kasar silase pakan komplit yang berbahan dasar eceng gondok (Eichornia crassipes).

\section{METODE PENELITIAN}

\section{Waktu dan Tempat Penelitian}

Penelitian dilaksanakan pada November sampai Desember 2019, yang terbagi dalam dua tahap. Tahap pertama yaitu pembuatan silase pakan komplit bertempat di Laboratorium Valorisasi Limbah dan tahap kedua yaitu analisa kadar lemak kasar bertempat di Laboratorium Kimia Pakan, Fakultas Peternakan Universitas Hasanuddin, Makassar.

\section{Materi Penelitian}

Alat yang digunakan dalam penelitian ini yaitu parang sebagai pencacah, terpal, karung, timbangan analitik, skop, gunting, $\mathrm{pH}$ meter, Thermometer, vacum cleaner dan semua peralatan yang digunakan pada analisis lemak kasar. 
D.Yuvita, J. Mustabi, A. Asriany / Buletin Nutrisi dan Makanan Ternak 14 (2) : 14-27

Bahan yang digunakan dalam penelitian ini adalah eceng gondok $(\mathrm{PK}=$ 11,58; $\mathrm{LK}=1,29 ; \mathrm{SK}=25,05 ;$ Kadar Air $=87,98)$, konsentrat indukan $(\mathrm{PK}=17,27$; $\mathrm{SK}=18,69 ; \mathrm{LK}=0,21)$ yang diperoleh dari pabrik industri pakan Fakultas Peternakan Universitas Hasanuddin Makassar, selotip, label dan bahan kimia yang digunakan untuk analisis lemak kasar.

Bahan penyusun konsentrat yang digunakan yaitu tongkol jagung, tepung rese, tepung ikan, garam, dedak, jagung, bungkil kelapa, urea, molases, Brand Gluten Feed (BGF), Soy Bean Meal (SBM), Corn Gluten Meal (CGM), gandum, pollard, kulit kopi, onggok, tepung udang, $\mathrm{CaCO}_{3}, \mathrm{DCP}$.

\section{Metode Pelaksanaan a.Rancangan penelitian}

Rancangan penelitian yang digunakan adalah rancangan acak lengkap (RAL) dengan menggunakan 4 perlakuan dan 4 ulangan. Perbandingan penggunaan eceng gondok dan konsentrat yaitu $70 \%$ : $30 \%$. Adapun perlakuannya adalah sebagai berikut.

P0 = Lama fermentasi 0 hari

P1 = Lama fermentasi 10 hari

P2 = Lama fermentasi 20 hari

P3 = Lama fermentasi 30 hari

\section{b. Prosedur penelitian}

Pembuatan silase pakan komplit eceng gondok diawali dengan pencacahan eceng gondok $(2-3 \mathrm{~cm})$, dijemur hingga kering udara (KA $60 \%$ ). Dilakukan penimbangan pada bahan yang digunakan yakni eceng gondok sebanyak 33,6 kg dan konsentrat sebanyak 14,4 kg. Pencampuran dan pengadukan bahan hingga homogen (eceng gondok + konsentrat) sesuai perlakuan kemudian dimasukkan kedalam silo, di vacum sampai tidak ada udara didalam silo dan ditutup rapat dengan selotip kemudian diberi label sesuai perlakuan dan ulangan. Setelah waktu proses ensilase pakan komplit selesai berdasarkan masing-masing perlakuan, dilakukan pengujian karakteristik dan kandungan lemak kasar pada silase pakan komplit.

Parameter yang diamati adalah karakteristik fisik (warna, tekstur, aroma, $\mathrm{pH}$, suhu dan kadar air) dan kandungan lemak kasar silase pakan komplit. Pengamatan 
fisik silase dilakukandengan membuat skor untuk setiap kriteria. Nilai untuk setiap kriteria yang digunakan sebagai pembanding kualitas silase adalah sebagai berikut (Soekanto dkk, 1980) :

- Warna (skor 1-3) : 3. Hijau alami atau kekuningan

2. Hijau gelap atau kecoklatan

1. Coklat sampai hitam

- Bau (skor 1-3): $\quad 3$. Asam agak manis

2. Asam

1. Busuk

- Tekstur (skor 1-3) : 3. Padat tidak mengelupas sama dengan bahan asal

2. Agak lembek

1. Lembek

Analisa kadar air dengan metode pengeringan (oven) yaitu cawan porselin yang akan digunakan disterilkan terlebih dahulu di oven pada suhu $130^{\circ} \mathrm{C}$, kemudian didinginkan dalam desikator selama 15 menit dan timbang (x). Menimbang dengan teliti kurang lebih 1 gram sampel (y) dan dimasukkan ke dalam cawan porselin kemudian dimasukkan dalam oven pada suhu $130^{\circ} \mathrm{C}$ untuk dikeringkan selama semalaman. Cawan porselin berisi sampel yang sudah di oven, didinginkan dalam desikator selama 30 menit, lalu ditimbang beratnya (z) (SNI 01-2891-1992).

Kadar BK $=\frac{\mathrm{Z}-\mathrm{X}}{\mathrm{Y}} \times 100 \%$

Kadar Air $=100 \%-$ BK

Keterangan

$\mathrm{X} \quad$ : Berat cawan porselin kosong (gr)

Y : Berat sampel (gr)

Analisa lemak kasar dilakukan berdasarkan analisis proksimat (AOAC, 1998).Untuk mengetahui kandungan lemak kasar dilakukan prosedur sebagai berikut

1. Menimbang sampel sebanyak 1 gram (a gram), kemudian dimasukkan kedalam tabung reaksi. 
2. Larutan chloroform diberikan sebanyak $10 \mathrm{ml}$ kemudian tabung reaksi ditutup agar larutan tidak menguap, dikocok sampai homogen dan dibiarkan selama 24 jam.

3. Sampel disaring dengan menggunakankertas saring kemudian pipet sebanyak $5 \mathrm{ml}$.

4. Sampel yang telah dipipet dimasukkan kedalam cawan porselin yang telah ditimbang berat kosongnya (b gram).

5. Sampel dimasukkan dalam oven selama 24 jam pada suhu $105^{\circ} \mathrm{C}$, kemudian didinginkan dalam desikator selama 30 menit dan ditimbang (c gram).

Hasil pengamatan dihitung berdasarkan rumus sebagai berikut :

Kadar Lemak Kasar $=\mathrm{P} \frac{c-b}{a(\text { gram })} \times 100 \%$

Keterangan :

$$
\begin{aligned}
& \mathrm{P}=\text { Faktor pengenceran } \frac{10}{5}(\mathrm{ml}) \\
& \mathrm{a}=\text { Berat sampel }(\mathrm{g}) \\
& \mathrm{b}=\text { Berat cawan kosong }(\mathrm{g}) \\
& \mathrm{c}=\text { Berat sampel setelah dioven }(\mathrm{g})
\end{aligned}
$$

\section{c. Analisis Data}

Data yang diperoleh pada penelitian dianalisis menggunakan ANOVA (sidik ragam). Apabila perlakuan berpengaruh nyata dilanjutkan dengan uji Duncan (Gasperz, 1991).

$$
\mathbf{Y i j}=\boldsymbol{\mu}+\boldsymbol{\alpha} \mathbf{i}+\varepsilon \mathbf{i j}
$$

Keterangan :

Yij = Nilai pengamatan pada perlakuan ke $i$ dan ulangan ke $j$

$\mu \quad=$ Nilai tengah umum

$\alpha i \quad=$ Pengaruh perlakuan

Eij = pengaruh kesalahan penelitian pada perlakuan ke $i$ dan ulangan ke $j$,

$\mathrm{i} \quad=$ banyaknya perlakuan $(1,2,3,4)$

$\mathrm{j} \quad=$ banyaknya ulangan $(1,2,3,4)$ 


\section{HASIL DAN PEMBAHASAN}

\section{Pengujian Karakteristik Silase Pakan Komplit yang Berbahan Dasar Eceng Gondok (Eichornia crassipes)}

Hasil penelitian pengujian karakteristik silase pakan komplit berbahan dasar eceng gondok dapat dilihat pada Tabel 1.

Tabel 1.Rata-rata pengujian karakteristik silase pakan komplit yang berbahan dasar eceng gondok (Eichornia crassipes)

\begin{tabular}{ccccc}
\hline Perlakuan & Warna & Bau & Tekstur & Suhu $\left({ }^{\circ} \mathrm{C}\right)$ \\
\hline P0 & 3 & 3 & 3 & 34 \\
P1 & 2 & 2 & 3 & 27,72 \\
P2 & 2 & 2 & 2 & 28,5 \\
P3 & 2 & 2 & 2 & 28,35 \\
\hline
\end{tabular}

Keterangan : $\quad$ P0 = Lama fermentasi 0 hari; P1 = Lama fermentasi 10 hari; P2 = Lama fermentasi 20 hari; P3 = Lama fermentasi 30 hari ;Warna (3. Hijau alami atau kekuningan; 2.Hijau gelap atau kecoklatan; 1.Coklat sampai hitam), Bau (3. Asam agak manis; 2. Asam; 1. Busuk), Tekstur (3. Padat tidak mengelupas sama dengan bahan asal; 2. Agak lembek; 1. Lembek).

Sifat-sifat bahan serta perubahan-perubahan yang terjadi pada pakan dapat digunakan untuk menilai dan menentukan mutu pakan. Sifat fisik berguna sebagai homogenisitas pengadukan ransum, cara penyimpanan, dan pengangkutan bahan. Warna silase merupakan salah satu indikator kualitas fisik silase, warna yang seperti warna asal merupakan kualitas silase yang baik dan silase yang berwarna menyimpang dari warna asal merupakan silase yang berkualitas rendah.Pengamatan fisik yang dilakukan terhadap silase pakan komplit berbahan dasar eceng gondok, termasuk dalam kategori berkualitas baik karena rata-rata perlakuan memperlihatkan hasil yang hampir sama, yaitu berwarna hijau gelap atau kecoklatan, fenomena itu mulai tampak pada masa ensilase 10 hari. Diduga karena adanya proses respirasi yang masih terjadi selama proses ensilase, sebagaimana pendapat Reksohadiprodjo (1988) yang menyatakan perubahan warna yang terjadi pada tanaman yang mengalami proses ensilase disebabkan oleh perubahan-perubahan yang terjadi dalam tanaman karena proses respirasi aerobik yang berlangsung selama persediaan oksigen masih ada, sampai gula tanaman habis. Gula akan teroksidasi menjadi $\mathrm{CO}_{2}$ dan air, dan terjadi panas hingga temperatur naik. Bila temperatur tak dapat terkendali, silase akan 
berwarna coklat tua sampai hitam. Hal ini menyebabkan turunnya nilai makanan, karena banyak sumber karbohidrat yang hilang dan kecernaan protein turun, yaitu pada temperatur $55^{\circ} \mathrm{C}$.Selanjutnya dijelaskan bahwa, warna coklat pada silase disebabkan karena adanya pigmen phatophytin suatu derivat chlorophil yang tak ada magnesiumnya.

Bau atau aroma silase merupakan salah satu indikator untuk menentukan kualitas fisik, karena warna dapat menunjukkan ada tidaknya penyimpangan aroma yang terjadi pada silase limbah pertanian dari bahan asalnya. Aroma pada silase memiliki aroma yang asam karena pada proses ensilase berlangsung terjadi proses fermentasi.Rata-rata bau yang dihasilkan pada penelitian ini adalah asam dan masih dalam kategori baik. Hal ini sesuai dengan pendapat Saun dan Heinrichs (2008) bahwa silase yang baik akan mempunyai bau seperti susu fermentasi karena mengandung asam laktat, bukan bau yang menyengat. Utomo (1999) menambahkan bahwa aroma silase yang baik agak asam, bebas dari bau manis, bau amonia, dan bau $\mathrm{H}_{2} \mathrm{~S}$. Silase dengan atau tanpa penambahan starter memiliki aroma cenderung asam, sehingga setiap perlakuan yang berbeda tidak mempengaruhi aroma silase. Berdasarkan hal tersebut aroma terbaik pada perlakuan P1, P2, dan P3 (skor 2 : asam) dibandingkan dengan P0 (skor 3 : asam agak manis). Menurut Departemen Pertanian (1980), silase dengan kriteria aroma kurang asam termasuk dalam silase dengan kualitas sedang.

Tekstur merupakan salah satu indikator untuk menentukan kualitas fisik silase, karena semakin padat tekstur yang dihasilkan menunjukkan bahwa silase berkualitas baik.Berbeda halnya apabila tekstur silase limbah pertanian yang tidak padat maka silase memiliki kualitas yang rendah.Rataan nilai tekstur pada hari ke 0 dan hari ke 10 adalah 3 yang artinya padat tidak mengelupas sama dengan bahan asal dan pada hari ke 20 dan hari ke 30 adalah 2 yang artinya agak lembek. Tekstur silase yang baik ditunjukkan pada perlakuan P0 (lama fermentasi 0 hari) dan P1 (lama fermentasi 10 hari). Hal ini sesuai dengan pendapat Siregar (1996) menyatakan bahwa, secara umum silase yang baik mempunyai ciri-ciri yaitu tekstur masih jelas seperti alamnya. Hasil penelitian Syarifuddin (2006) melaporkan bahwa tekstur silase 
pada berbagai umur pemotongan (20 hingga 80 hari) menunjukkan tekstur yang remah.

Suhu silase pada pengamatan hari ke 10 sampai ke 30 berkisar antara 27$28^{\circ} \mathrm{C}$. Kondisi ini menunjukkan bahwa silase dalam keadaan baik. Sesuai dengan hasil penelitian Ridwan et al. (2005) yang melaporkan bahwa suhu silase yang dihasilkan pada semua perlakuan berkisar antara $26-28^{\circ} \mathrm{C}$. Suhu silase masih dikatakan baik karena suhu panen yang dihasilkan masih beberapa derajat berada di bawah suhu lingkungan. Sebaliknya apabila melebihi suhu lingkungan $5-10^{\circ} \mathrm{C}$ berarti silase tersebut diduga telah terkontaminasi mikoorganisme yang lain seperti kapang dan jamur. Semakin cepat proses ensilase berarti mempercepat kondisi kedap udara dan merangsang tumbuhnya bakteri asam laktat untuk membentuk asam laktat dan tidak terjadi panas yang berkepanjangan sehingga suhu stabil. Hidayat dan Indrasanti (2011) menyatakan bahwa suhu silase mulai konstan pada hari ke-14. Sedangkan Hermanto (2011) menyatakan bahwa fermentasi awal menyebabkan temperatur dalam silo meningkat dan $\mathrm{pH}$ mulai turun akibat terdapatnya asam organik khususnya asetat dalam silo.

\section{Kandungan pH Silase Pakan Komplit yang Berbahan Dasar Eceng Gondok (Eichornia crassipes)}

Nilai pH (derajat keasaman) merupakan salah satu indikator atau parameter untuk mengetahui pengaruh proses ensilase terhadap nilai nutrien pada silase berkadar air tinggi, pH lebih rendah menunjukkan kualitas lebih baik (Kung dan Nylon, 2001).

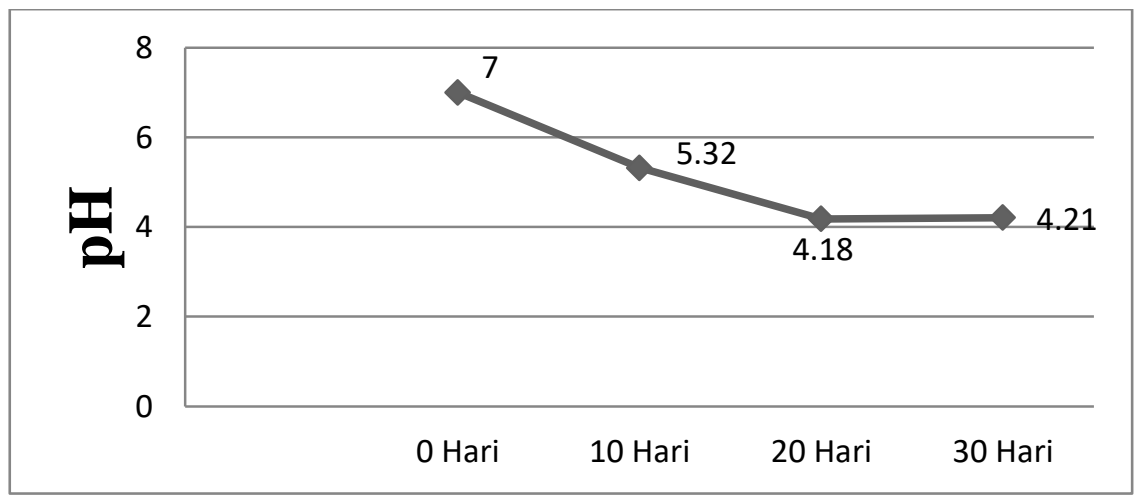

Gambar 2. Rataan Kandungan pH Silase Pakan Komplit yang Berbahan Dasar Eceng Gondok (Eichornia crassipes) 
D.Yuvita, J. Mustabi, A. Asriany / Buletin Nutrisi dan Makanan Ternak 14 (2) : 14-27

Hasil analisis sidik ragam menunjukkan bahwa perlakuan memberikan pengaruh yang nyata $(\mathrm{P}<0,05)$ terhadap kandungan $\mathrm{pH}$ silase pakan komplit berbahan eceng gondok. Hasil uji lanjut Duncan (Lampiran 1) terlihat bahwa P0 berbeda dengan perlakuan lainnya (P1, P2 dan P3) tetapi tidak ada perbedaan antara P2 dan P3.Hal ini menunjukkan bahwa lama fermentasi 20 dan 30 hari mempunyai $\mathrm{pH}$ yang tidak berbeda.

Gambar 2, terlihat bahwa $\mathrm{pH}$ tertinggi pada lama fermentasi 0 hari (P0) sedangkan terendah $(4,18)$ dari lama fermentasi 20 hari. Hal ini menunjukkan bahwa produksi asam laktat silase pakan komplit pada penyimpanan 20 hari lebih banyak dari penyimpanan 0, 10 dan 30 hari. Menurut Kung dan Shaver (2001) menyatakan bahwa $\mathrm{pH}$ silase berhubungan dengan produksi asam laktat pada proses ensilase, $\mathrm{pH}$ yang rendah mencerminkan produksi asam laktat yang tinggi. Terjadinyapenurunan nilai $\mathrm{pH}$ pada silase disebabkan oleh meningkatnya jumlah mikroorganisme terutama bakteri asam laktat yang dapat mempercepat terjadinya ensilase sehingga $\mathrm{pH}$ yang dihasilkan lebih rendah.Perlakuan $\mathrm{pH}$ yang semakin menurun (ke arah asam) menunjukkan bahwa proses silase telah berlangsung.

Nilai pH dari penelitian ini adalah 4,21 sampai 7, ini menunjukkan bahwa selama proses fermentasi menurunkan $\mathrm{pH}$ sebesar 2,79. Tinggi rendahnya nilai derajat keasaman silase sangat bergantung terhadapcepat atau lambatnya pembentukan asam-asam organik terutama asam laktat. Pada penelitian Woolford (1984) menyatakan bahwa cepatnya pembentukan asam laktat akan disertai dengan meningkatnya kondisi asam. Hal ini akan menyebabkan turunnya $\mathrm{pH}$ silase, sehingga akan menghambat pertumbuhan bakteri Clostridia, karena pada $\mathrm{pH}<4,2$ aktifitas bakteri Clostridia akan terhenti sempurna. Asam laktat mempunyai pengaruh paling besar terhadap penurunan $\mathrm{pH}$ silase, akan tetapi asam organik lain seperti asam asetat ikut berperan terhadap penurunan $\mathrm{pH}$ sehingga kondisi silase tetap asam.

\section{Kandungan Lemak Kasar Silase Pakan Komplit yang Berbahan Dasar Eceng} Gondok (Eichornia crassipes)

Kadar lemak kasar dalam analisis proksimat ditentukan dengan mengekstraksikan bahan pakan dalam pelarut organik. Zat lemak terdiri dari karbon, 
oksigen dan hidrogen. Lemak yang didapatkan dari analisis lemak ini bukan lemak murni akan tetapi campuran dari berbagai zat yang terdiri dari klorofil, xantofil, karoten dan lain-lain (Murtidjo, 1987). Kandungan lemak kasar silase pakan komplit yang berbahan dasar eceng gondok dapat dilihat pada Gambar 3.

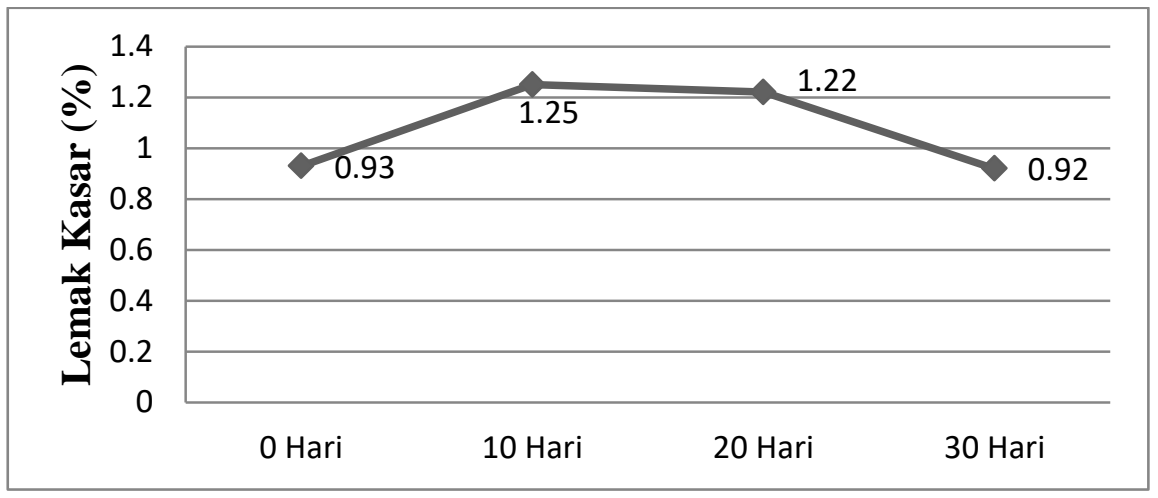

Gambar 3. Rataan Kandungan Lemak Kasar Silase Pakan Komplit yang Berbahan Dasar Eceng Gondok (Eichornia crassipes)

Hasil analisis sidik ragam menunjukkan bahwa perlakuan tidak berpengaruh nyata $(\mathrm{P}>0,05)$ terhadap kandungan Lemak Kasar silase pakan komplit. Hal ini menunjukkan bahwa lama penyimpanan $0,10,20$, dan 30 hari tidak berbeda kandungan lemak kasarnya.

Gambar 3, terlihat lama penyimpanan 10 hari mempunyai kandungan lemak kasar tertinggi $(1,25 \%)$ dan terendah pada lama fermentasi 30 hari (P3). Peningkatan kadar lemak selama fermentasi disebabkan kandungan lemak kasar yang berasal dari massa sel mikroba yang tumbuh dan berkembang biak pada media selama fermentasi (Budiman, 2014).Hal ini didukung oleh Soeparno (1998) menyatakan bahwa pada proses fermentasi silase, terdapat aktivitas bakteri yang menghasilkan asam lemak cukup tinggi sehingga kandungan lemak cenderung meningkat, akan tetapi kandungan lemak kasar yang terlalu tinggi pada bahan pakan ternak ruminansia juga tidak terlalu bagus karena dapat mengganggu proses fermentasi bahan pakan dalam rumen ternak. Menurut (Preston dan Leng, 1987) menyatakan bahwa standar kandungan lemak kasar bahan pakan ternak ruminansia berkisar di bawah 5\%. 
Kandungan lemak kasar yang diperoleh pada penelitian ini 0,92 sampai 1,25 $\%$. Terjadi peningkatan kandungan lemak kasar sekitar 0,33 \% selama waktu fermentasi. Pada penelitian Wati., dkk (2018) didapatkan hasil peningkatan lemak kasar silase rumput odot dengan penambahan Lactobacillus plantarum dan molases sebesar $1,58 \%$ pada lama waktu inkubasi yang berbeda. Hal ini diduga semakin lama proses inkubasi menyebabkan terjadinya perombakan karbohidrat menjadi asam lemak, sehingga dapat meningkatkan kandungan lemak.

\section{KESIMPULAN}

Berdasarkan hasil dari pembahasan disimpulkan bahwa silase pakan komplit yang berbahan dasar eceng gondok (Eichornia crassipes) termasuk dalam kategori baik berdasarkan pengujian karakteristik. Lama fermentasi yang berbeda berpengaruh nyata terhadap kandungan $\mathrm{pH}$ silase tapi tidak ada perbedaan kandungan lemak kasar pada silase tersebut. Lama fermentasi 20 hari adalah yang terbaik dalam pembuatan silase pakan komplit berbahan eceng gondok.

\section{DAFTAR PUSTAKA}

Association of Official Analytical Chemist. 1998. Official Methods Analysis The Association of Analytical Chemist, Airlington : VA.112

Budiman, R. M. 2014. Analisis Kandungan Bahan Ekstrat Tanpa Nitrogen (BETN) dan Lemak Kasar Pada Rumput Taiwan (Pennisetum purpereum) dan Kulit Buah Pisang Kepok yang Difermentasi dengan Trichoderma sp., Jurusan Peternakan, Fakultas Pertanian, Peternakan dan Perikanan, UMPAR. Parepare.

Fuskhah, E. 2000.Eceng gondok (Eichhornia crassipes (Mart) Solm) sebagai alternatif sumber bahan pakan, industri dan kerajinan. Jurnal Ilmiah Sainteks. 7 (4): $226-234$.

Hermanto, 2011.Sekilas Agribisnis Peternakan Indonesia.konsep pengembangan peternakan, menuju perbaikan ekonomi rakyat serta meningkatkan gizi generasi mendatang melalui pasokan protein hewani asal peternakan.

Kung, D and S. Nylon,. 2001. Tropical Tuber Crops. Jhon Willey and Sons, Chishester. UK. 
Kung, L. and R. Shaver,. 2001. Interpretation and use of silage fermentation analysis reports. J Focus on Forage 13(3):1-5.

Marlina, N dan S. Askar. 2001.Nilai gizi eceng gondok dan pemanfaatan sebagai pakan ternak non ruminansia. Jurnal Balai Penelitian Ternak. Bogor. Temu Teknis Fungsional Non Peneliti. Hal 58-62.

Murtidjo.1987. Pedoman Beternak Ayam Broiler. Kanisius, Yogyakarta.

Preston dan J. A. Leng, 1987.Drought Feeding Strategies Theory and Fractice. Feel Valley Printery, New South Wales.

Reksohadiprodjo, S, 1988. Pakan Ternak Gembala. BPFE, Yogyakarta.

Ridwan, R, S. Ratnakomala, Kartina, G dan Widyastuti, Y., 2005. Pengaruh Penambahan Dedak Padi dan Lactobacillus planlarum 1BL-2 dalam Pembuatan Silase Rumput Gajah (Pennisetum purpureum).Media Peternakan. 28 (3): $117-123$.

Riswandi. 2014. Kualitas silase eceng gondok (Eichhornia crassipes) dengan penambahan dedak halus dan ubi kayu. Jurnal Peternakan Sriwijaya. 3 (1) : 16.

Saun, R.J.V. and A. J. Heinrichs,. 2008.Troubleshooting silage problems: How to identify potential problem.Proceddings of the Mid-Atlantic Conference; Pennsylvania, 26-26 May 2008. Penn State's Co llage.Pg 2-10.

Siregar, M.E. 1996. Pengawetan Pakan Ternak. Penebar Swadaya. Jakarta.

Soekanto L., P. Subur, N. Soegoro., U. Ristianto, Muridan, Soewondo. R. M. Toha, Udiyo, S. Purwo, Musringan, M. Sahari dan Astute. 1980. Laporan Proyek Konservasi Hijauan Makanan Ternak, Jawa Tengah. Direktur Jenderal Peternakan. Departemen Pertanian dan Fakultas Peternakan, Universitas Gadjah Mada, Yogyakarta.

Soeparno. 1998. Ilmu dan Teknologi Daging cetakan ke tiga. Gajah Mada University Press, Yogyakarta.

Syarifuddin, N.A, 2006.Karakteristik dan Persentase Keberhasilan Silase Rumput Gajah pada Berbagai Umur Pemotongan. Fakultas Peternakan Universitas Lambung Mangkurat Banjarbaru. Banjarmasin.

Utomo, R. 1999. Teknologi Pakan Hijauan. Fakultas Peternakan, Universitas 
D. Yuvita, J. Mustabi, A. Asriany / Buletin Nutrisi dan Makanan Ternak 14 (2) : 14-27

Wati, W.S, Mashudi, dan A. Irsyammawati. 2018. Kualitas silase rumput odot (Pennisetum purpureum cv. Mott) dengan penambahan Lactobacillus plantarum dan molases pada waktu inkubasi berbeda. Jurnal Nutrisi Ternak Tropis. 1 (1) : 45-53.

Woolford, M. K., 1984. The Silage Fermentation, Marcel Dekke, Inc. NewYork. 